\title{
Analysis of the Properties Aluminium Casting Motorcycle Forks Arm after Compression Test
}

\author{
Daniela Kalincová ${ }^{1}$, Miroslava Ťavodová ${ }^{1}$, Sylvia Kuśmierczak ${ }^{2}$ \\ ${ }^{1}$ Faculty of Environmental and Manufacturing Technology, Technical University in Zvolen, Študentská 26, 960 53. Slo- \\ vak Republic..E-mail: kalincova@tuzvo.sk, tavodova@tuzvo.sk \\ ${ }^{2}$ Faculty of Mechanical Engineering, University of J. E. Purkyně in Usti nad Labem, Pasteurova 7, 400 01. Czech Repub- \\ lic. E-mail: sylvia.kusmierczak@ujep.cz
}

The article describes the course of a pressure test that was made to determine the maximum force in the case of breaking the integrity of the casting. Observation of the forks arm deformation can be done with using sensors on the universal tensile testing machine. Using a high-speed camera to monitor this test will provide results in digital form that can serve to further research. Subsequently, analysis of the material properties of the AISi7Mn0.3 casting is described, using the methods of evaluation of mechanical and structural properties. Periodic tests check the castings status to ensure recurrent quality in order to achieve the required safety in accordance with the standards for road vehicles.

Keywords: AlSi7Mg0.3 alloy, compression test, mechanical properties, microstructure, fractography

\section{References}

[1] KLIMENT, J., ŠOLC, M. (2017). IATF 16949:2016 - prechod na novú verziu štandardu kvality v automobilovom priemysle. In Kvalita\&Spoločenská zodpovednost'. DRaM Žilina. Vol. XXV, No. 1. 2017. ISSN 1335-9231.

[2] KOTUS, M., JANKAJOVÁ, E., PETRÍK, M. (2015). Quality control of aluminium melt in production process. In Research in Agricultural Engineering. Vol. 61 (2015), Special Issue. pp. 43-47. ISSN 1212-9151.

[3] SUJOVÁ, E., ČIERNA, H., MOLENDA, M. (2016). Evaluation of human reliability in selected activities in the railway industry. In Management systems in production engineering. 2016. s. 191-197. ISSN 2299-0461.

[4] KALINCOVÁ, D., ŤAVODOVÁ, M., ČIERNA, H. (2015). Root cause analysis for identifying defects in the process of cylinder head castings from aluminium alloy. In Manufacturing Technology ISSN 1213-2489. - Vol. 15, no. 4 (2015), p. 546-553.

[5] KOTEK, L. ŤAVODOVÁ, M., JONÁK, M., KALINCOVÁ D., TUMA, Z., SUJOVÁ, E. (2016). Using of high speed motion analysis for compression test of motorcycle forks arm. In 17th Mechatronika 2016. Vol. 17. ISBN 978-80-01-05882-4.

[6] TillovÁ, E., CHAlupovÁ, M., HURTAlOVÁ, L., BONEK, M., DOBRZANSKI, L. A, (2011). Structural analysis of heat treated automotive cast alloy, Journal of Achievements in Materials and Manufacturing Engineering/JAMME, 47(1), 19-25.

[7] MICHNA, Š., LUKÁČ, I. (2012). Praktická fraktografie, FVTM, UJEP, 2012, s. 237, ISBN 978-80-7414-496-7.

[8] NÁPRSTKOVÁ, N., KUŚMIERCZAK, S., CAIS, J. (2013). Modification of AlSi7Mg0.3 Alloy by Stroncium. In Manufacturing Technology, Vol. 13, No. 3, pp. 373-380, 2013, ISSN 1213-2489.

[9] BOLIBRUCHOVÁ, D., RICHTARECH, L. (2016). Possibilities of Using Al-Si-Mg Alloys with Higher Fe Content for Demanding Castings In. Manufacturing technology No2, 2016, ISSN 1213-2489.

[10] BOLIBRUCHOVÁ, D., RICHTARECH, L. (2013). Effect of adding iron to the AlSi7Mg0.3 (EN AC 42100 , A356) alloy. In: Manufacturing Technology, Vol. 13, No. 3, pp. 276-281. ISSN 1213-2489

[11] KUŚMIERCZAK, S. (2011). The usage of confocal laser microscope by solving student projects. In International Multidisciplinary Conference. $9^{\text {th }}$ edition, 19-21 May, 2011, Baia Mare - Nyiregyhaza, Romania - Hungary, $p$. 149 - 152, ISBN 978-615-5097-18-8.

[12] MÜLLER, M. (2017). Effects of Aluminium Microparticles and Surface Treatment of AlCu4Mg on Mechanical Properties of Adhesive Bond Strength, In Manufacturing Technology, February 2017, Vol. 17, No. 1, pp. 66-71, 2017, ISSN 1213-2489.

[13] KUŚMIERCZAK, S. (2015). Methods of evaluation degraded parts. Engineering for Rural Development, Vol 14 (January), 2015, pp. 790-794.

[14] NÁPRSTKOVÁ, N., KALINCOVÁ, D. (2015). Influence of additional chemical components on machining properties of selected aluminium - silicon alloy. Conference: 14th International scientific conference: Engineering for rural development, 2015. Pp. 766-771.

[15] PEREC, A., ŤAVODOVÁ, M. (2016) Abrasive water jet cutting depth optimization by Taguchi approach. In Manufacturing technology. ISSN 1213-2489. - Vol. 16, no. 3 (2016), p. 585-590. 